Journal of Engineering and Applied Sciences 14 (1): 145-152, 2019

ISSN: 1816-949X

(C) Medwell Journals, 2019

\title{
Investigation the Performance of Parabolic Solar Water Heater with Different Tracking System-Basra City Case Study
}

\author{
Maher K. Taher, Ali K. Al-Sayyab and Mohammed A. Abdulwahid \\ Southern Technical University, Basra, Iraq
}

\begin{abstract}
The performance of parabolic solar water heater is quite sensitive to the latitude, day of operationas well as the tracking mode. In this study, a five different tracking mode are invited North-South rotate and East-West rotate over the four season of the year and to perform the suitable one for using in Basra city an mathematical model was used and programming with EES program. The results show that the performance of all tracking systems are closely at noon and the tracking system mode 5 give the highest collected energy with $34 \%$ increase from East-West rotate mode.
\end{abstract}

Key words: Parabolic solar water heater, tracking mode, solar energy, performance, East-West, tracking mode

\section{INTRODUCTION}

With increase the awareness of the climate global warming changes, many institutes and organizations recommended to reduce the emissions of carbone dioxide (United Nations Framework Convention on Climate Change, 1998). The emissions of carbone dioxide can be reduced by either increase the device efficiency or by reducing the dependence on burning crude oil as an energy source by using green energy source like wind or solar energy. Solar energy is a great cheapest source of green energy worldwide which can be used directly for heating by using flat plate or parabolic solar heater or by converting it into electricity by using photovoltaic cell. To get maximum solar intensity with effective performance the solar devices should be either tracking the sun continuously or the solar devices should be fix with suitable direction and orientation regarding to the sun. Many studies are adopting to investigate the performance and orientation of many solar energy-collecting devices. Jamadi (2010) did an study for using solar water heater in Zhejiang as China's city they recommended to reduce the manufacturing cost and improve the technology of water heater. Han et al. (2010) and Jamadi (2016) perform a theoretical study using numeric iteration for performance of solar water heater they predicted that the collected energy is directly proportion with solar radiation and is inversely proportional with useful energy. So, the highest thermal efficiency is predicted with $0.02-0.03 \mathrm{~kg} / \mathrm{sec}$ mass flow rate of heating water. Study the effect of heating water mass rate of flow on the parabolic solar water heater efficiency, she found that the thermal efficiency of collector in Summer is $<2$ -
$5 \%$ in Winter. Taher (2017) and Al-Sayyab et al. (2015) by using a mathematical models was programed in engineering equation solver find that there is one optimum monthly tilted angle for photovoltaic cell and the optimum yearly tilted angle of photovoltaic cell located in different location is not equal to the latitude of these locations. Tayade et al. (2015) did an experimental study the performance of parabolic solar water heater over sunshine period, they detected that the maximum solar energy is collected at noon period. Yassen and Khalaf (2012) and Yassen (2012) study the effect heating fluid rate of mass flow on collected heat. He found that the collected solar energy by fluid is inversely proportional with its flow rate while the thermal efficiency is directly proportional with heating fluid rate of mass flow (Rajamohan et al., 2016). Did an experimental study to perform the effect of parabolic dish concentrator using on performance of solar water heating system the study show that the using parabolic dish concentrator will improve the temperature of the absorber tube and increase the efficiency by $23.96 \%$. So, the combined effect of parabolic dish and conical absorber would provide better heat gain for solar water heating system. Maher perform an experimental study to investigating the effect of parabolic solar water heater heating pipe glassing and focus located in Basra city, the result show that the parabolic water heater of $25 \mathrm{~cm}$ focus with 1-inch diameter glassing heating pipe give good performance from other pipe size and focus. Terron-Hernandez et al. (2018) presents a prediction tool to analyze the energy performance of compound parabolic solar concentrator using ray tracing software to determine the energy availability in two scenarios. First one is static with tilted

Corresponding Author: Maher K. Taher, Southern Technical University, Basra, Iraq 

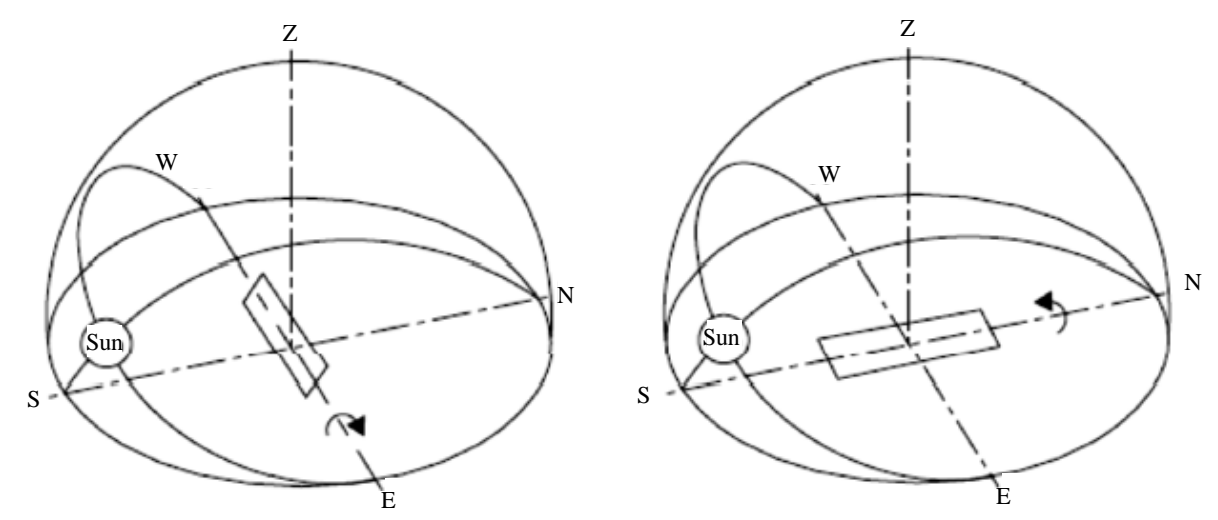

Fig. 1: Different tracking mode (Duffie and Beckman, 2003)

angle of $21^{\circ}$ and the second tilted angle is varied according to three seasonal positions: $0^{\circ}$ for Summer, $16^{\circ}$ for Spring/Autumn and $32^{\circ}$ of or Winter. The study found that using of the varying tilted angle throughout the year will increase the energy availability by $22 \%$ than the static setup (Fig. 1).

\section{MATERIALS AND METHODS}

Solar radiation geometry: In order to find the beam energy falling on surface having any orientation to study the performance of cylindrical parabolic solar water heater with different tracking mode the covering equations of solar energy for finding the solar intensity should be obtain by the following equations (Al-Sayyab et al., 2013; Sukhatme and Nayak, 2008):

$$
\begin{gathered}
I_{C}=I_{b} R_{b} \\
I_{d}=H_{d}(\bar{a}+\bar{b} \cos ) \frac{I_{0}}{H_{o}} \\
\bar{a}=0.422+\left(\frac{0.113}{\frac{H_{d}}{H_{a}}}\right) \\
\bar{b}=2(1-a)(\sin \omega s-\omega \cos ) /(\omega s-0.5 \sin 2 \omega s) \\
R_{B}=\frac{\operatorname{Cos} \theta}{\operatorname{Cos} \theta_{z}} \\
\operatorname{Cos} \theta_{z}=\operatorname{Sin} \phi \operatorname{Sin} \delta+\operatorname{Cos} \delta \operatorname{Cos} \delta \operatorname{Cos} \phi \operatorname{Sin} \omega
\end{gathered}
$$

$$
\begin{gathered}
\delta=23.45 \operatorname{Sin}\left[\frac{360}{365}(284+\mathrm{n})\right] \\
\frac{\mathrm{H}_{\mathrm{g}}}{\mathrm{H}_{\mathrm{o}}}=\mathrm{a}+\mathrm{b}\left(\frac{\mathrm{S}}{\mathrm{S}_{\max }}\right) \\
\mathrm{H}_{0}=\frac{24}{\pi} \mathrm{I}_{\mathrm{sc}}\left(1+0.033 \operatorname{Cos}\left(\frac{360 \mathrm{n}}{365}\right)+\omega_{\mathrm{s}} \operatorname{Sin} \varnothing\right. \\
\operatorname{Sin} \delta+\operatorname{Cos} \delta \operatorname{Cos} \varnothing \operatorname{Sin} \omega \mathrm{s}
\end{gathered}
$$

$$
\begin{aligned}
& \mathrm{a}=-0.309+0.539 \cos \varnothing+0.0693 \mathrm{E}_{\mathrm{L}}+0.29\left(\frac{\mathrm{s}}{\mathrm{S}_{\max }}\right) \\
& \mathrm{b}=-1.527-1.027 \operatorname{Cos} \varnothing+0.0926 \mathrm{E}_{\mathrm{L}}-0.359\left(\frac{\mathrm{s}}{\mathrm{S}_{\max }}\right)
\end{aligned}
$$

$$
\text { Io }=1.367\left(1+0.033 \operatorname{Cos}\left(\frac{360 \pi}{365}\right) \cos \theta_{z}\right.
$$

$$
\mathrm{C}=0.409+0.5016 \operatorname{Sin}\left(\omega_{\mathrm{s}}-60\right)
$$

$$
\mathrm{D}=0.6609 .0 .4767 \operatorname{Sin}\left(\omega_{\mathrm{s}}-60\right)
$$

Cylindrical parabolic solar heater tracking modes: A cylindrical parabolic collector is oriented with its focal axis 
pointed either in the East-West (E-W) or North-South $(\mathrm{N}-\mathrm{S})$ direction, in the East West orientation the focal axis is horizontal while in the North South orientation the focal axis may be horizontal or inclined.

Tracking mode 1: In this mode the collector rotate around $\mathrm{E}-\mathrm{W}$ axis, so, the tilted angle of the aperture plane is depends on location latitude and declination angle, so, for each day there is a declination angle, so that, the tilted angle should be daily adjusted (once per day). The tilted angle is equal to:

$$
\beta=\varnothing-\delta
$$

The beam radiation incidence angle for this mode can be obtained by:

$$
\operatorname{Cos} \theta=\operatorname{Sin}^{2} \delta+\operatorname{Cos}^{2} \delta \operatorname{Cos} \omega
$$

Tracking mode 2: In this mode the collector rotate around $\mathrm{E}-\mathrm{W}$ axis so the tilted angle of the aperture plane is depends on location latitude, declination angle and the time, so, for each day the tilted angle should be hourly adjusted (once per day). The tilted angle is equal to:

$$
\operatorname{Tan}(\varnothing-\beta)=\frac{\operatorname{Tan} \delta}{\operatorname{Cow} \omega}
$$

The beam radiation incidence angle for this mode can be obtained by:

$$
\operatorname{Cos}^{\ominus}=\left(1-\operatorname{Cos}^{2} \delta \operatorname{Sin}^{2}\right)^{1 / 2}
$$

Tracking mode 3: In this mode the collector rotate around $\mathrm{N}-\mathrm{S}$ axis, so, the tilted angle of the aperture plane is depends on location latitude, declination angle and the time, so, for each day the tilted angle should be hourly adjusted (once per day). The tilted angle is equal to:

$$
\beta=\operatorname{Tan}^{-1}\left(\frac{\operatorname{Cos} \delta \operatorname{Sin} \omega}{\operatorname{Sin}_{\varnothing} \operatorname{Sin}_{\delta}+\operatorname{Cos}_{\delta} \operatorname{Cos}_{\varnothing} \operatorname{Cos}_{\omega}}\right)
$$

The beam radiation incidence angle for this mode can be obtained by:

$$
\operatorname{Cos} \theta=\left(\left(\operatorname{Sin}_{\varnothing} \operatorname{Sin}_{\delta}+\operatorname{Cos}_{\delta} \operatorname{Cos}_{\varnothing} \operatorname{Cos}_{\omega}\right)^{2}+\operatorname{Cos}^{2} \delta \operatorname{Sin}^{2} \omega\right)^{1 / 2}
$$

Tracking mode 4: In this mode the collector rotate around $\mathrm{N}-\mathrm{S}$ axis, so, the tilted angle of the aperture plane is depends $\mathrm{n}$ location latitude only, so that, the collector is fixed with tilted angle according to location:

$$
\beta=\varnothing
$$

For this mode the beam radiation incidence angle is equal to declination angle:

$$
\theta=\delta
$$

Tracking mode 5: In this mode the collector rotate around $\mathrm{N}-\mathrm{S}$ axis, so, the tilted angle of the aperture plane is depends on location latitude and declination angle, so, for each day there is a declination angle, so that, the tilted angle should be daily adjusted (once per day). The tilted angle is equal to:

$$
\beta=|\phi-\delta|
$$

In this mode the beam radiation incidence angle is equal to:

\section{RESULT AND DISCUSSION}

Tracking modes over Spring season: According to solar calendar 21 of March represent the first day in the solar year which is the first Spring day and 20 Jun. represent the end of Spring season. From Fig. 2 at the moment of sunrise the amount of collected energy by any tracking mode is the lowest and then increases gradually until reach the peak value around noon, then after noon it decreases gradually until reaches the lowest value when the Sun to be set. This due to the effect of air mass that directly proportional with zenith angle variation, the solar radiation is depleted during its passage though the atmosphere before reaching the Earth's surface. At sunset the reduction of solar intensity will increase due to increasing zenith angle (suspend more distance, more air mass) while in sunrise solar intensity will increase due to zenith angle decreasing (suspend less distance, less air mass) (Fig. 3).

Figure 2 the collected energy by tracking mode 1 and 2 is identical. The collected energy by mode 5 is always more than others modes because of this mode 5 is continuously rotate about $\mathrm{N}-\mathrm{S}$ axis that will make the solar beam normal intendance on the aperture plane at all time (reduce the reflected out the heating pipe). So, the collected energy by mode 1 and 2 at morning and afternoon is always less than other modes. Because of for these modes the incident angle of solar radiation is too large as compared with other modes for the same period (morning and afternoon) that will increase the reflected solar radiation out of the heating pipe location. At noon the incidence goes to be minimum for all modes that make its performance nearest to other (Fig. 4). 

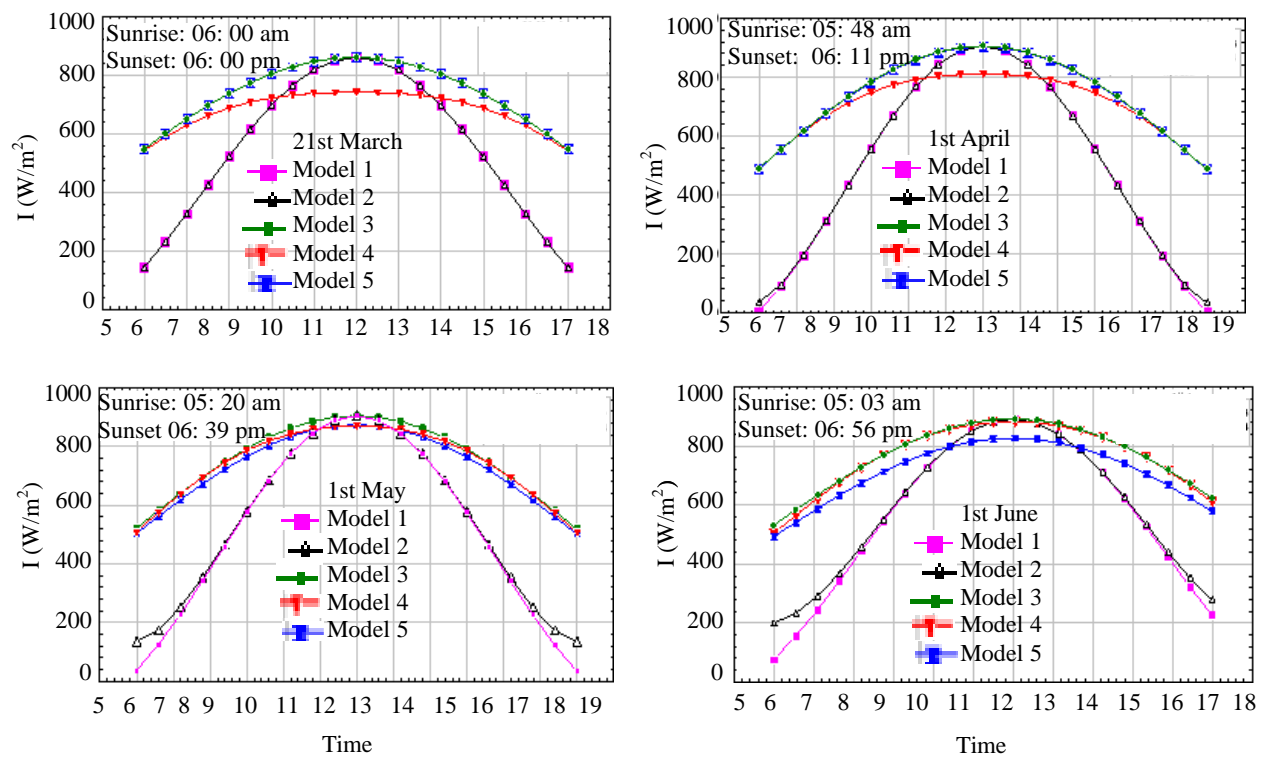

Fig. 2: Tracking models performance over Spring season

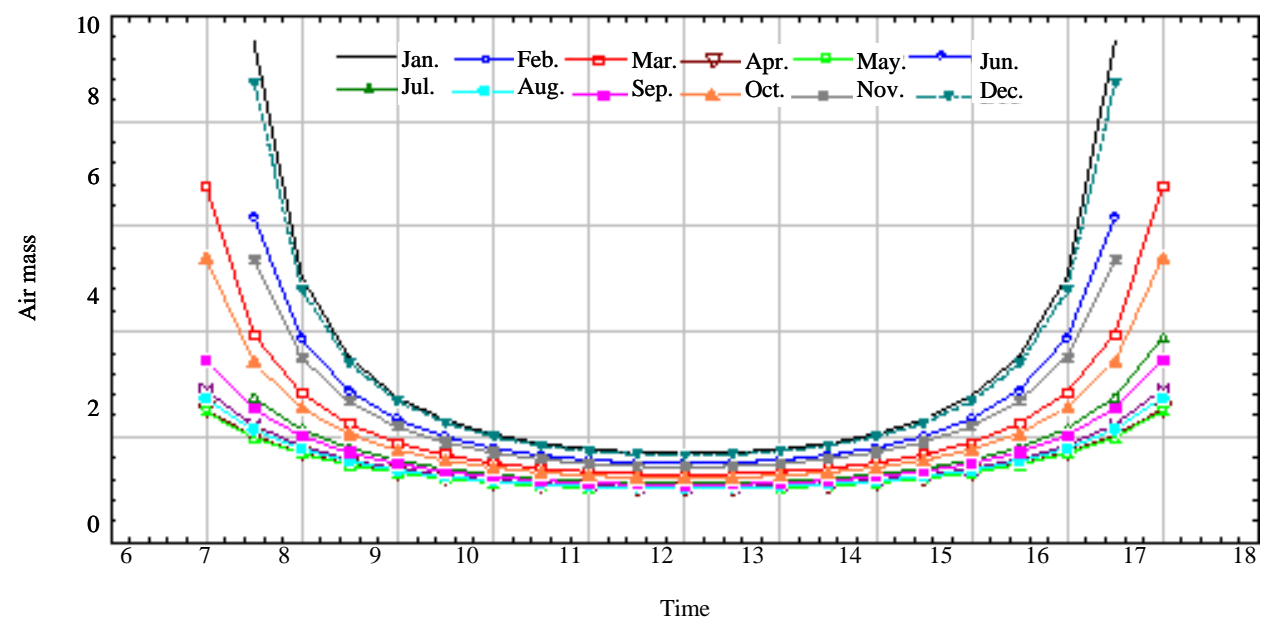

Fig. 3: Air mass variation for different month
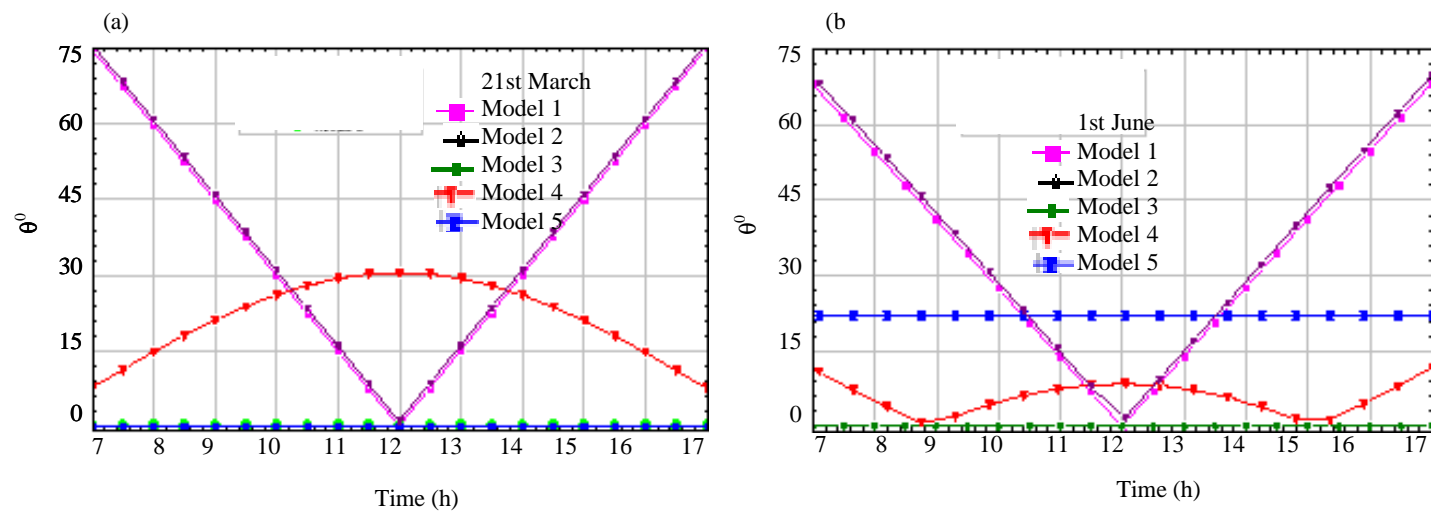

Fig. 4: Incident angle for studied tracking modes Spring season 
(a)

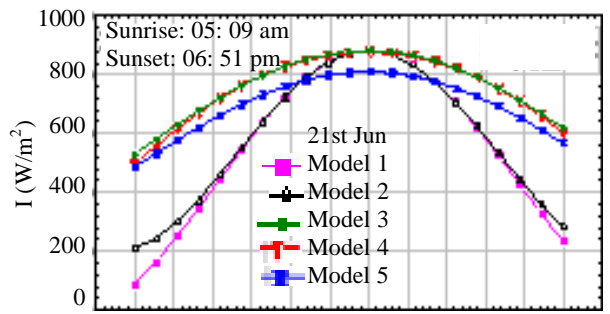

(c)

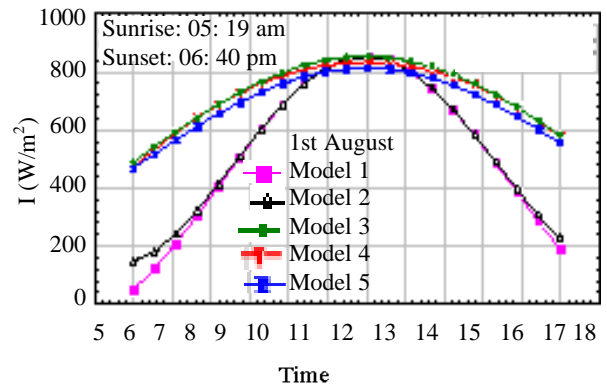

Time

Fig. 5: Tracking models performance over Summer season

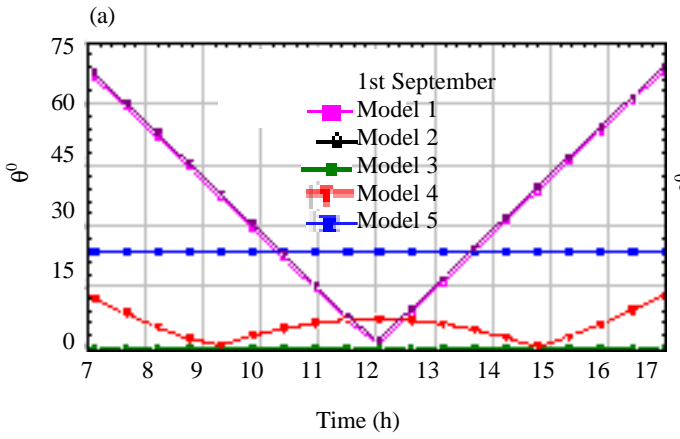

(b)

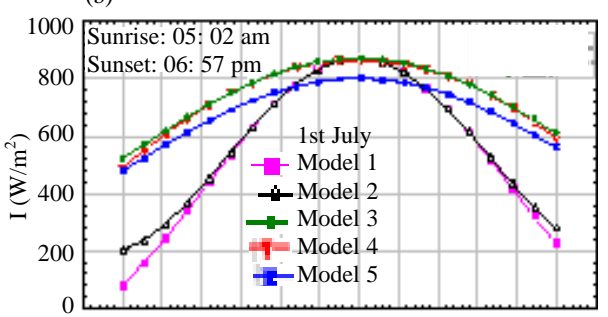

(d)

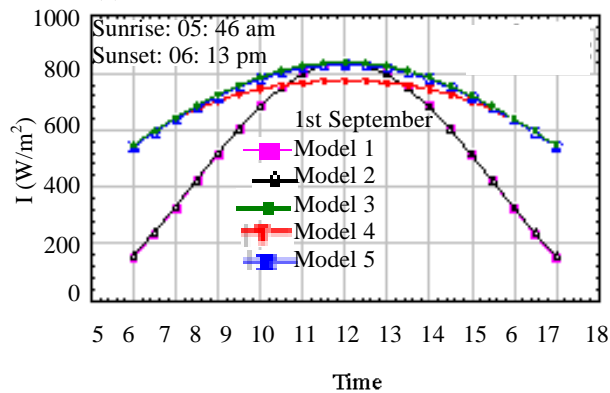

(b)

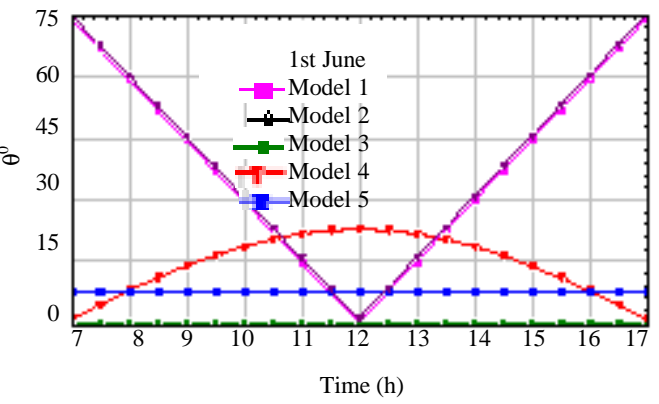

Fig. 6: Incident angle for studied tracking modes Summer season

The 21st of June represent the first Summer day and 23 September represent the end of Summer season. From Fig. 5. For the 3 months of Summer season the collected energy by mode 5 and 3 is always more than others modes because of over all this period the solar beam incidence angle with aperture plane is too small as compared with other modes (Fig. 6) this will decrease the reflected solar ray out of the heating pipe location reduce the reflected out the heating pipe). So, the collected energy by mode 1 and 2 at morning and afternoon period is always less than other modes because of the mode 1 and 2 are not adjusted continuously per day. There for the solar beam incidence angle with aperture plane is too large at this period as compared with other modes that will increase the reflected solar ray out of the heating pipe location (Fig. 6).

Also from Fig. 5, for month of September. The collected energy by mode 3 will increase while the collected energy by mode 4 will decrease as compared with other month of this season this due to the incident angle of solar radiation will decrease this will decrease the reflected solar ray out of the heating pipe location (reduce the reflected out the heating pipe). Moreover, the oboist for mode 3 (Fig. 6).

Tracking modes over Autumn season: The 24 st of September represent the first Autumn season day and 20 December represent the end of season. From Fig. 7, for all the months of Autumn season the collected energy by mode 5 and mode 4 is more than others modes because of over all this period the solar beam incidence angle with aperture too small as compared with other modes (Fig. 8) this will decrease the reflected solar ray out of the pipe location reduce the reflected out the heating pipe). So, the collected energy by mode 3 at noon always less than other modes because of the mode solar beam incidence angle with aperture plane is too at this period as compared with other modes that will increase the reflected solar beam out of the heating location (Fig. 8 and 9). 

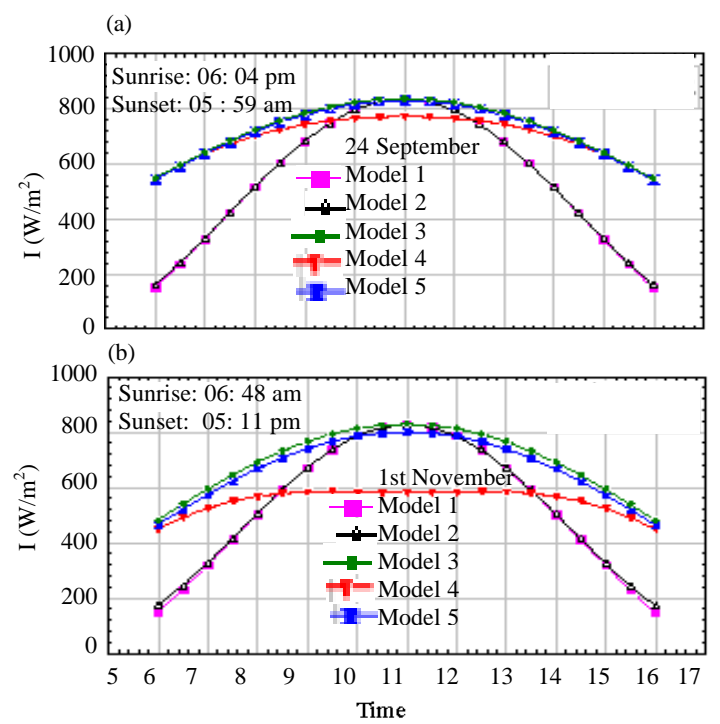

Fig. 7: Tracking models performance over Autumn season

(a)

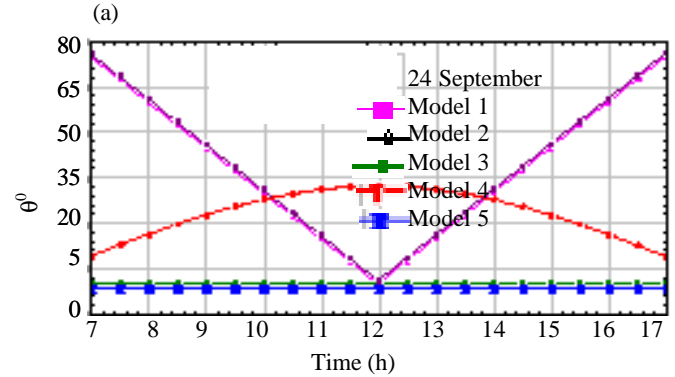

(c)
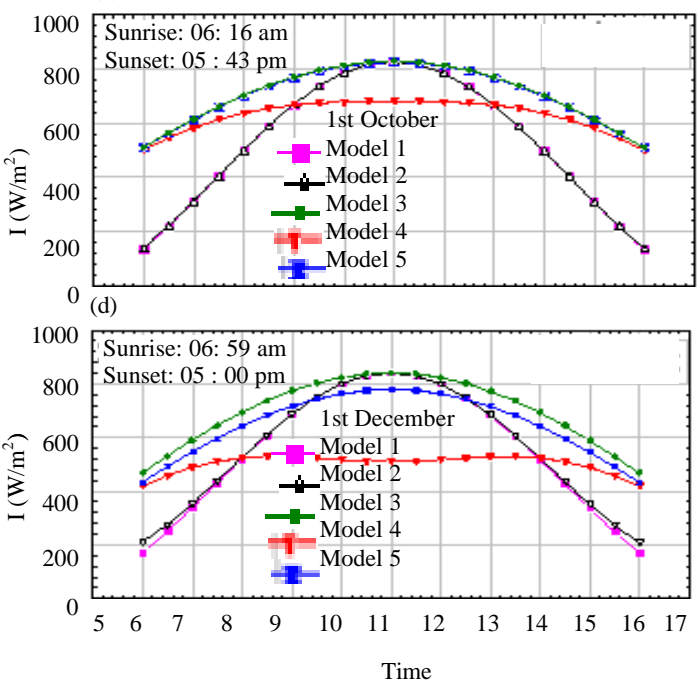

(b)

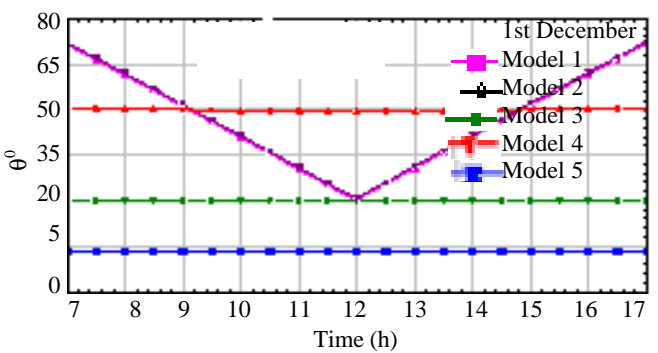

Fig. 8: Incident angle for studied tracking modes Autumn season

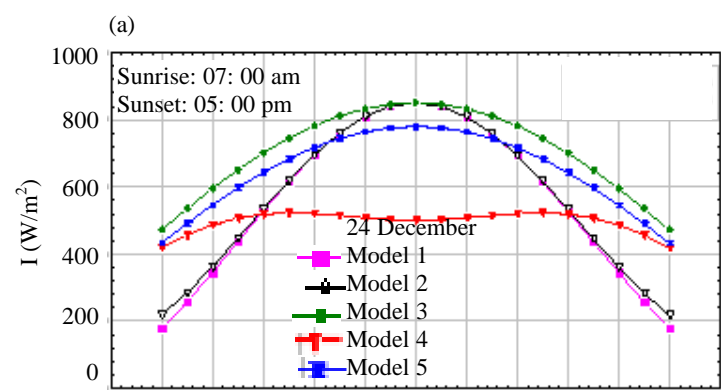

(b)

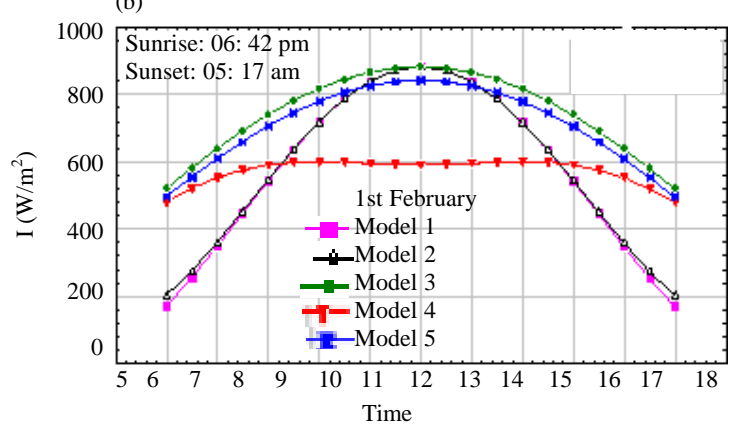

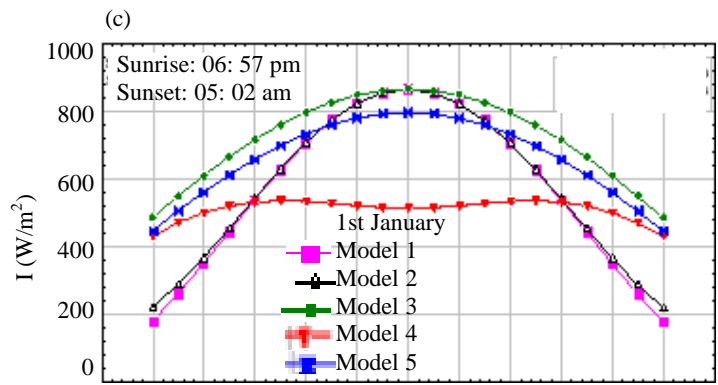

(d)

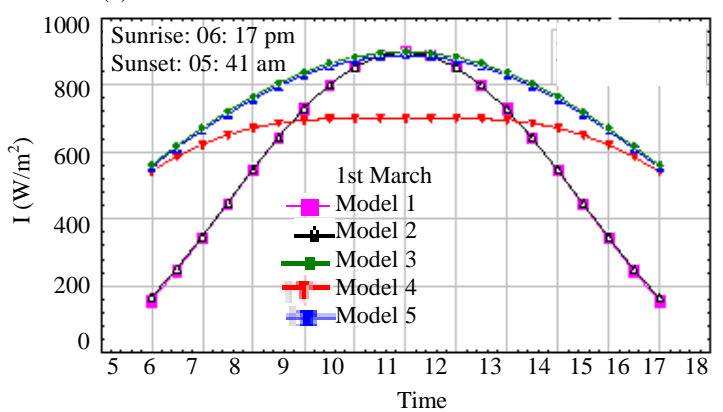

Fig. 9: Tracking models performance over Autumn season 
(a)

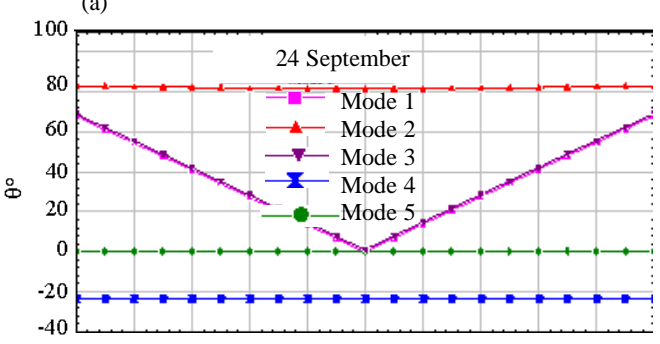

(b)

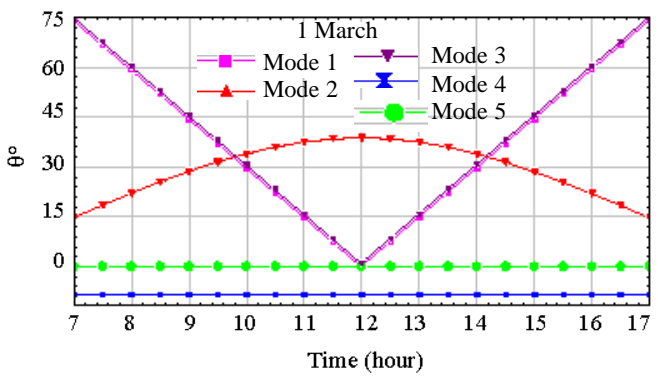

Fig. 10: Incident angle for studied tracking modes Winter season

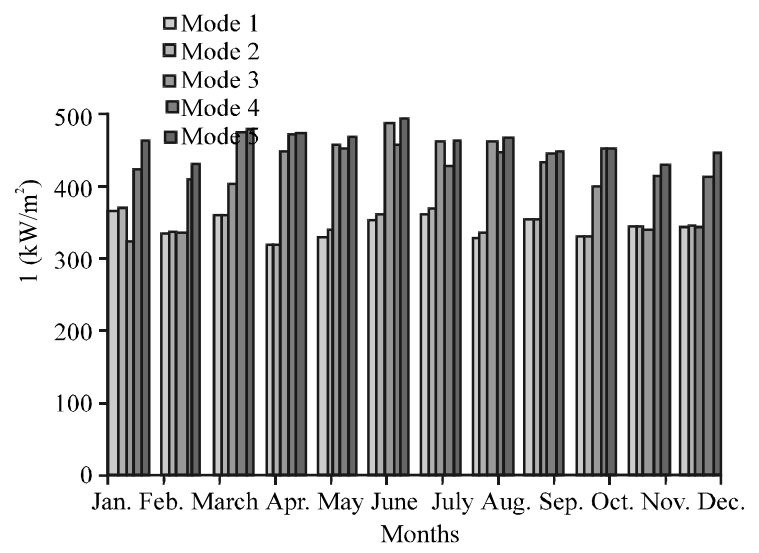

Fig. 11: Monthly collected energy by different modes

Tracking modes over Winter season: Winter season is the last season of the solar year its start from 21 of December and from Fig. 9, for all period of Winter season, the greatest collected energy is always that collected and mode 4 because of over all this period the solar beam incidence angle with aperture plane compared with other modes (Fig. 10), this will decrease the reflected solar beam out of location. In addition, the collected energy with mode 3 at noon is always the lowest from others solar beam incident angle. Best tracking mode over the year: In the light of prevous the perphormance of cylindrical prabolic solar water heater that operating with tracking mode 5 over all the year's season is always the beast from othres invesitge modes, due to this mode its tracking around N-S once per day, so the solar bean incedent angle by this mode is always the lowest over the moths (Fig. 4-10) that will reduce the reflected energy out

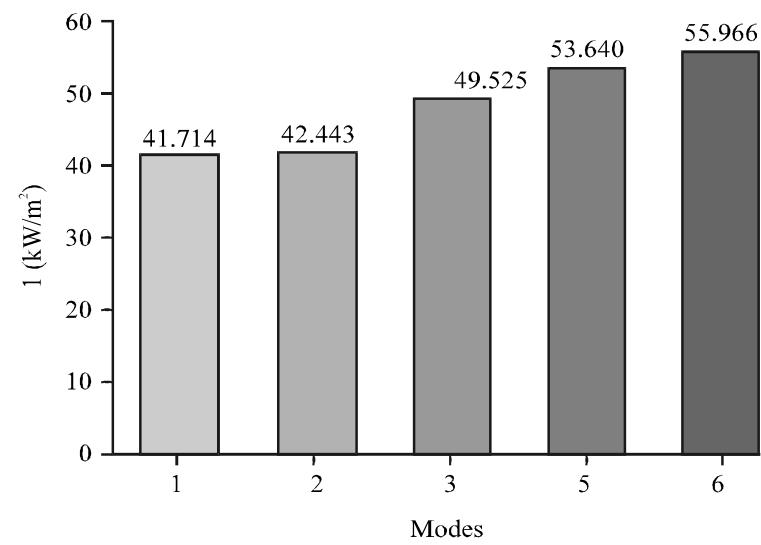

Fig. 12: Yearly collected energy by different modes

of the heating pipe (increase the collected energy) (Fig. 11). So, the Mode 5 give 34\% collected solar energy more than that of E-W rotate modes (mode 1 and 2) over the year (Fig. 12).

\section{CONCLUSION}

The performance of solar water heater with investigate tracking modes is closely at noon due to its incidence is identical at this period. At the moment of sunrise and sunset the amount of collected energy by any tracking mode is the lowest as compared with other period due to the effect of air mass that directly proportional with zenith angle variation.

The solar water heater performance with tracking Mode 5 give the highest collected solar energy with 34\% more than that of E-W rotate modes (mode 1 and 2) over the year. For serise connection of prabolic solar water heater and for shaft arragment, tracking mode 5 in not sutible so mode 4 are suitable for this type of arragment. The solar water heater with tracking mode 4 give collected energy reduction of $4 \%$ from mode 5 .

\section{NOMENCLATURE}

Symbol/Definition

$\mathrm{I}_{\mathrm{b}}=$ Hourly Beam solar radiation $\left(\mathrm{kJ} / \mathrm{m}^{2}\right)$

$I_{c}=$ Hourly Concentration solar radiation $\left(\mathrm{kJ} / \mathrm{m}^{2}\right)$

$I_{\mathrm{d}}=$ Hourly Diffusion solar radiation $\left(\mathrm{kJ} / \mathrm{m}^{2}\right)$

$\mathrm{I}_{0}=$ Hourly extraterrestrial solar radiation $\left(\mathrm{kJ} / \mathrm{m}^{2}\right)$

$\mathrm{I}_{\mathrm{g}}=$ Hourly Global solar radiation $\left(\mathrm{kJ} / \mathrm{m}^{2}\right)$

$\mathrm{H}_{\mathrm{d}}=$ Monthly average of Diffusion solar radiation $\left(\mathrm{kJ} / \mathrm{m}^{2}\right.$.day)

$\mathrm{H}_{0}=$ Monthly average of extraterrestrial solar radiation $\left(\mathrm{kJ} / \mathrm{m}^{2}\right.$.day)

$\mathrm{H}_{\mathrm{g}}=$ Monthly average of Global solar radiation

$\mathrm{n}=$ Day number of the year $\left(\mathrm{kJ} / \mathrm{m}^{2}\right.$.day $)$ 
$\mathrm{S}=$ Monthly average of Day length (hour)

$\mathrm{S}_{\max }=$ Monthly average of maximum day length hour (km)

$\mathrm{E}_{\mathrm{L}}=$ Elevation above the see level $\left(^{\circ}\right)$

$\mathrm{R}_{\mathrm{b}}=$ Tilted factor for beam radiation $\left(^{\circ}\right)$

$\delta=$ Declination angle $\left(^{\circ}\right)$

$\beta=$ Tilted angle of parabolic $\left(^{\circ}\right)$

$\phi=$ Latitude of location $\left({ }^{\circ}\right)$

$\omega=$ Hour angle $\left(^{\circ}\right)$

$\omega_{2}=$ Hour angle $\left(^{\circ}\right)$

$\theta=$ Incidence angle $\left(^{\circ}\right)$

$\theta_{z}=$ Zenith angle $\left(^{\circ}\right)$

\section{REFERENCES}

Al-Sayyab, A.K.S. and M.K. Taher, 2013. Optimum tilted angle of photovoltaic cell located in northern Iraq cities to get maximum generated electric power. National Renewable Energ. Conf. Their Appl., 2013: 162-177.

Al-Sayyab, A.K.S. and M.K. Taher, 2014. Optimum yearly tilted angle of photovoltaic cell to receive maximum solar radiation in southern Iraq Cities. Thi-Qar Univ. J. Eng. Sci., 5: 1-14.

Duffie, J.A. and W.A. Beckman, 2003. Solar Engineering of Thermal Processes. 4th Edn., John Wiley \& Sons, New Jersey, USA., ISBN: 9781118418123 , Pages: 936.

Han, J., A.P.J. Mol and Y. Lu, 2010. Solar water heaters in China: A new day dawning. Energy Policy, 38: 383-391.

Jamadi, F., 2016. Experimental investigation of effect of oil mass flow changes on parabolic trough collector efficiency in a solar water heater system. Intl. J. Tech. Phys. Prob. Eng., 8: 88-94.
Rajamohan, G., P. Kumar, M. Anwar and T. Mohanraj, 2016. Analysis of solar water heater with parabolic dish concentrator and conical absorber. Proceedings of the 29th International Symposium on Malaysian Chemical Engineers (SOMChE 2016) Vol. 206, December 1-3, 2016, Curran Associates Inc., Miri, Malaysia, ISBN:978-1-5108-4325-7, pp: 265-273.

Sukhatme, S.P. and J.K. Nayak, 2008. Solar Energy Principle of Thermal Collection and Storage. 3rd Edn., McGraw-Hill Education, New York, USA., ISBN-13:978-0-07-026064-1, Pages: 433.

Taher, M.K., 2017. An experimental study of parabolic solar water heater performance located in Basra city. J. Kerbala Univ., 15: 26-31.

Tayade, M.G., R.E. Thombre and S. Dutt, 2015. Performance evaluation of solar parabolic trough. Intl. J. Sci. Res. Publ., 5: 1-5.

Terron-Hernandez, M., M.I. Pena-Cruz, J.G. Carrillo, U. Diego-Ayala and V. Flores, 2018. Solar ray tracing analysis to determine energy availability in a CPC designed for use as a residential water heater. Energ., 11: 291-308.

United Nations Framework Convention on Climate Change, 1998. Kyoto protocol to the United Nations framework convention on climate change. http://unfccc.int/resource/docs/convkp/ kpeng.pdf.

Yassen, S.S.M.T.A. and H.J. Khalaf, 2012. Theoretical study of the compound parabolic trough solar collector. Tikrit J. Eng. Sci., 19: $1-9$.

Yassen, T.A., 2012. Experimental and theoretical study of a parabolic trough solar collector. Anbar J. Eng. Sci., 5: 109-125. 